\title{
Intimate Violence: A Study of Intersexual Homicide in Chicago*
}

\author{
Franklin E. Zimring, $\dagger$ Satyanshu K. Mukherjee,,$\dagger$

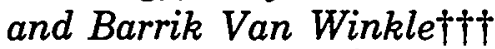

It is criminological cliclie that a person is safer in Central Park at three o'clock in the morning than in his or her own bedroom. This chestnut is based on a large body of researcl, covering a number of countries and many U.S. jurisdictions, suggesting that intimate violence is a large portion of total homicide. ${ }^{1}$ But homicide involving intimates is ripe for re-examination for three reasons. First, patterns of criminal violence have slifted in the United States as rates of homicide have increaased. ${ }^{2}$ Second, survey instruments and statistics on reported crime lave been used to suggest a recent and escalating epidemic of life-threatening intimate violence. ${ }^{3}$ These assertions can be tested best with death statistics,

* The research reported in this paper was made possible, and indeed instigated, by the cooperation of Richard J. Brzeczek, who was Superintendent of the Chicago Pohice Department at the time the study was.conducted. We wisb to thank him and the personnel of the Crimes Analysis Unit, Bureau of Investigative Services, for their kind assistance and toleration.

† Karl N. Llewellyn Professor of Jurispridence \& Director, Center for Studies in Criminal Justice, University of Chicago Law School.

t† Semor Criminologist, Australian Institute of Criminology.

tt† Project Assistant, Center for Studies in Criminal Justice, University of Chicago Law School.

'See, e.g., Family Violence passim (J. Eekelaar \& S. Katz eds. 1978).

2 See Federal Bureau of Investigation, U.S. Dep't of Justice, Uniform Crime Reports (1958-1982) [hereinafter cited as UNIPORM CRIME REPorts]. (The Federal Bureau of Investigation ("FBI") pubhshes its Uniform Crime Reports annually. The dates given hereinafter in citations refer to the year for which the data were collected. The Uniform Crime Reports generally is released during the year following data collection.) See also R. BLock, Violent Crime 39-60, 98 (1977); Block, Homicide in Chicago: A Nine-Year Study (19651973), 66 J. Crim. L. \& Criminology 496, 504 (1975); Block \& Zimring, Homicide in Chicago, 1965-1970, 10 J. Research Crime \& Delinq. 1, 10-11 (1973).

3 In one of the first national surveys on domestic violence, M. STrauss, R. GELLEs, \& S. STEINMETZ, Behind Closed Doors (1980), the authors argue on the basis of data collected in 1975 that "every year about one out of every six couples in the United States commits at least one violent act against his or her partner. If the period considered is the entire length of the marriage (rather than just the previous year), the result is 28 per cent." Id. at 32 . The survey covered 2143 currently unarried, co-residential couples; interviews were carried out with only one adult in the household present. The authors investigated violence of varying degrees of severity, ranging from thrown objects to gun and knife threats. Other relevant 
the most reliable long-term-trend indicators available on the war between the sexes. Finally, a specific analysis of intersexual killings is necessary because larger movements in the general homicide rate are dominated by killings with male victims and offenders. ${ }^{4}$ Patterns of violence between the sexes cannot be discerned unless they are segregated from aggregate homicide statistics.

This study is based on an analysis of the 151 homicides occurring in Chicago during 1981 that involved a victim and an offender (known or suspected) of different gender. Although our main research interest was violence between sexual intimates, the vagaries of police classification schemes and the arbitrariness of any single definition of intimacy led us to begin with the universe of all intersexual killings. This article discusses national trends and sets out in detail our Chicago findings. A concluding note addresses some of the theoretical puzzles generated by the study's findings, highlighting issues that deserve attention in future research. ${ }^{5}$

\section{Intersexual Homidide: The Chicago Data}

Criminal homicide has been a growth industry in the United States since the early 1960 's. ${ }^{6}$ But homicides known to the pohice involving spouses or other familial relationships have remained remarkably stable. Figure 1 tells the national statistical story, using aggregate data from the Uniform Crime Reports of the Federal Bureau of Investigation.

Since 1962, the aggregate total of homicides known to the pohice has nearly tripled, ${ }^{7}$ and adjusting the figures for changes in population $^{8}$ does hittle to dampen the magnitude of the increase or

works in this area are FAmiry Violence, supra note 1; M. Fregman, Violence in the Home (1979); R. Grlles, Family Violence (1979); M. Locktain, Family Violence: The Well Kept Secret (1979); Violence and the Family (M. Green ed. 1980).

- See, e.g., UnIform Crime Rrports, supra note 2, at 9 (1980); Block \& Zimring, supra note 2, at 4-7.

- A second article will counpare the Chicago results with other studies of intimate violence and will present data on intersexual hounicide in Australia and Canada.

- See UnIform Crime Reports, supra note 2, at 8 (1980); id. at 16 (1975) (Chart 5); id. at 7 (1970) (Chart 4); Zimring, Firearms and the Federal Law: The Gun Control Act of 1968, 4 J. Legal Stud. 133, 133 n.2 (1975). Prior te 1963, the rate of criminal homicide in the United States had tended to decline. See UnIrORM CrIME REPORTs, supra note 2, at 6 (1963).

7 Compare Unirorm Crime Reports, supra note 2, at 80 (1962) (Table 5) (7734 homicides) with id. at 6 (1981) (22,516 homicides).

s The United States population increased from an estimated $185,800,000$ in 1962 te approximately $221,800,000$ in 1980. Bureau of the Census, U. S. Dep'T of Commerce, Statistical Abstract of the United States 6 (101st ed. 1980) (Table 2). 


\section{FIGURE 1}

Spouse, Other Relative \& Total

HoMICIDE, U.S., 1962-1980

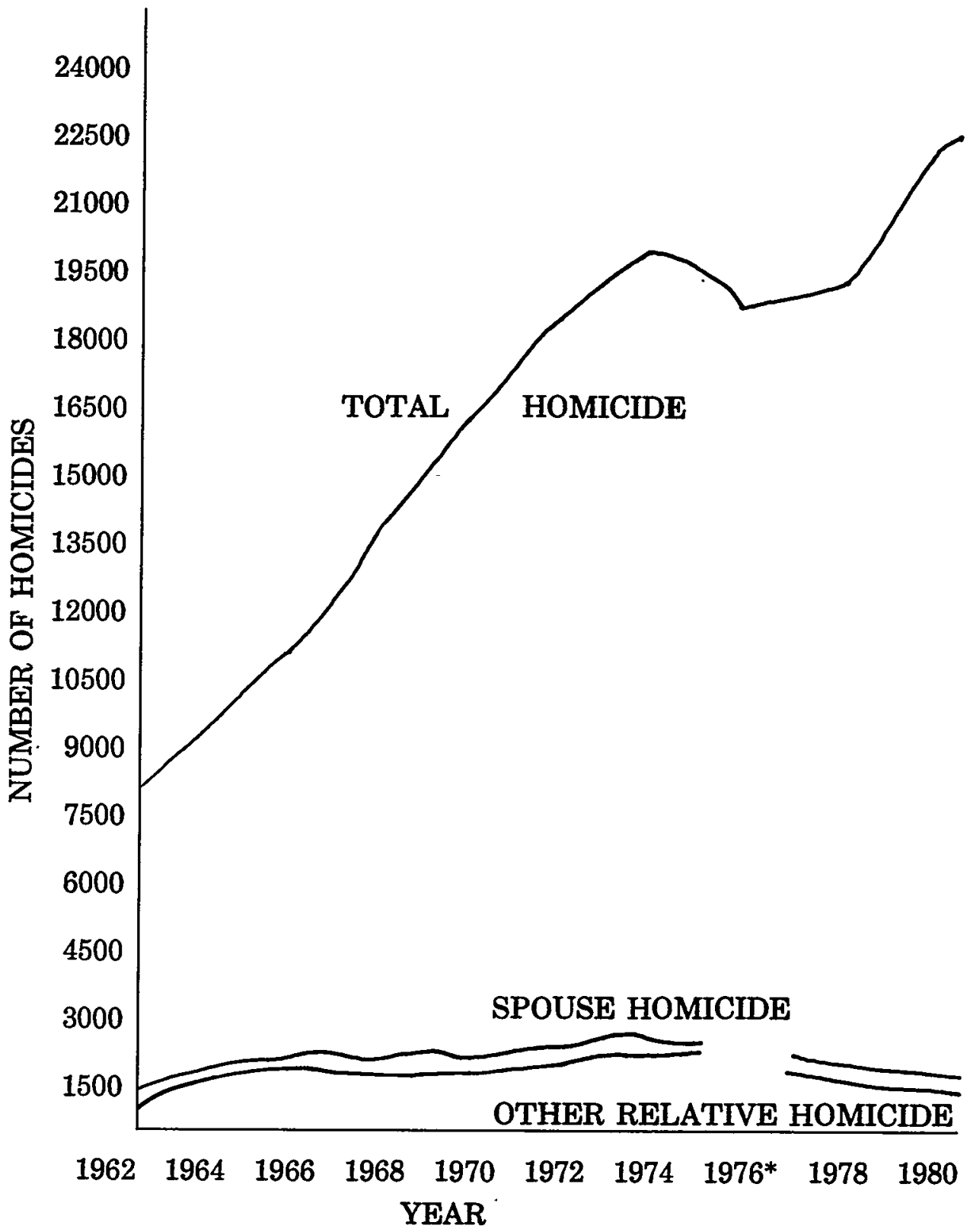

Source: Statistics derived from UnIForm CRIME Reports, supra note 2, passim (1962-1980).

* The Uniform Crime Reports for 1976 report that 26\% of the homicides in that year involved family members, with no further breakdown by relationship. 
the consistency in upward trend noted until the mid-1970's and from 1978 forward.

As Figure 1 indicates, trends in "spouse homicide" and "other relative" homicide show a stability sharply divergent from the statistics for aggregate killings. Pohice-classified spouse killings declined from $16.6 \%$ of total reported homicides in 1965 to slightly over $8 \%$ in 1980, while the proportion of lomicides involving other familial relationships declined from $14.4 \%$ to $7.8 \%$.

The relative decline in these categories of homicide is hardly a sociological surprise. Previous studies show that sharp increases in homicide are disproportionately concentrated in the category of males killing other males. ${ }^{\circ}$ The stability in the volume of spouse and "other relative" killings is remarkable. Between 1969 and 1980 , while the total number of homicides increased by over $50 \%$, the absolute number of spouse and other relative killings remained unchanged. When adjusted to reflect the increase in married households, the rate of spouse homicide actually declined from 4.3 per 100,000 such households in 1970 to 3.9 in $1980 . .^{10} \mathrm{We}$ are not aware of any previous studies that have observed a decline in the frequency of intimate violence during a period when the general homicide rate is increasing substantially. Though errors in classification may be numerous in crime reporting, ${ }^{11}$ it seems unlikely that such errors generate these sharply divergent trends.

We studied homicides reported to the Chicago Police Department during calendar year 1981 that involved a victim and a known or suspected offender of opposite sex. The case summaries

- This dynamic was first pointed out by the Finnish scholar Veli Verkko in V. VERKKo, Homicides and Suicides in Findand and Their Dependence on National Character 50-56 (1951). For additional discussion of this social phenomenon, see Block, supra note 2, at 504-05; Block \& Zimring, supra note 2, at 5-7.

10 In 1970 there were approximately $44,755,000$ married-couple households; in 1980 there were 48,180,000. Bureau or the Census, supra note 8, at 43 (103d ed. 1982) (Table 60). The approximate figures for spouse homicides are 1923 for 1970 and 1814 for 1980 . Compare UNIFORM CRIME REPorts, supra note 2, at 10 (1973) with id. at 12 (1980). One discriminant factor in this decline is the great improvement in emergency medicime of both response time and quality of care, particularly for the poor. There is no necessary reason why this should affect intimate homicide differentially, except that related attackers may be more prone to call quickly for medical and pohice aid.

12 The relationship between offender and victim is noted on police forms when known, but precise information on marital or intimate status is usually not germane or necessary in investigations, since most intimate homicides are what the pohice call "smokers," that is, cases in which the offender is apprehended, often willingly, at or near the scene of the crime. We have tried to distinguish these statuses, but the lumping of "legal marriage," separated, divorced, "common law" marriage, and "romantic involvement" relationships into larger and vaguer categories precludes any definitive analysis of the risks of violence associated with any one of these statuses. 
of all 1981 Chicago homicides produced a sample of 151 intersexual homicides, $17 \%$ of the 877 killings reported to the police. ${ }^{12} \mathrm{We}$ examined complete investigative case files for these 151 cases. Analyzing the entire universe of intersexual killings allowed us to subclassify the events and relationslips into categories useful for our purposes, ratlier than liaving to rely on aggregate statistics tliat produce an inevitably ligh margin of error. Table 1 reports the distribution of victims of intersexual homicide by race, sex, and ethnicity.

\section{TABLE 1}

Victims OF INTERSEXUAL Homicide, By Race/Ethnicity and Sex, Chicago, 1981

\begin{tabular}{|c|c|c|c|c|c|}
\hline \multicolumn{6}{|c|}{ Race/Ethnicity } \\
\hline & Black & White & $\begin{array}{l}\text { Hispanic } \\
\text { Surname }\end{array}$ & Other & Total \\
\hline Male & 57 & 9 & 1 & 3 & 70 \\
\hline Female & 55 & $\underline{22}$ & $\underline{4}$ & $\underline{0}$ & 81 \\
\hline Total & 112 & 31 & 5 & 3 & 151 \\
\hline
\end{tabular}

Source: Homicide Records and Case Files of the Chicago Police Department.

As Table 1 indicates, the war between the sexes takes its casualties in almost equal measure. Of the 151 victims of intersexual homicide, 81 were female; the remaining 70 were male. As usual, ${ }^{13}$ blacks were overrepresented: Chicago blacks, who compose about $40 \%$ of the population, ${ }^{14}$ account for $74 \%$ of all intersexual homicides, and black victims are almost evenly divided between females and males. White non-Hispanic homicide victims comprise $20 \%$ of the victim population, but liere female victims outnumbered males by over two to one. Victims with Hispanic surnames account for only five deaths in the 1981 sample, despite a 14\% share of Cliicago's population ${ }^{15}$ and higlı rates of general violence. ${ }^{16}$ Although

12 All hut three of these 151 cases were cleared as of January 15, 1982. Because the Chicago Police Department's 1981 lomicide analysis has not yet appeared, we are unable to give a full description of that year's intrasexual homicides; accordimgly, we have rehed upon 1980 lomicide statistics for purposes of comparison.

1s For example, although blacks composed only about $12 \%$ of tbe national population in 1980, see Bureau or THE Census, supra note 8, at 26 (103d ed. 1982) (Table 28), they made up $42 \%$ of the homicide victims that year, see UNIPORM CRIME REPORTS, supra note 2, at $11(1980)$.

14 See Bureau of the Census, supra note 8, at 22 (103d ed. 1981) (Table 26).

15 See id. 
the sex ratio for Hispanics may not be statistically significant because the number is so small, the fact that Hispanic victimization comprises only about $3 \%$ of total intersexual homicide in Chicago is worthy of note. ${ }^{17}$

Table 2, which reports the race and ethnicity of offenders,

TABLE 2

Percentage Distribution By Race/Ethnicity in Chicago for 1980 Population, 1980 Known Homicide Offenders, and 1981 Primary Intersexual Offenders*

1980 Chicago

Population

Homicide Offenders

(1980)

Intersexual

Offenders (1981)

\section{Race/Ethnicity

Black White

$\underline{\text { Hispanic }}$

Other

40

40

14

6

71

8

$20 * *$

1

78

16

$5^{* *}$

1

Source: Burkau of the Census, supra note 8, at 22 (103d ed. 1982) (Table 26); Burgau of the Census, U.S. Drp't of Commerce, State and Metropolftan Area Data Book 1982, at 372 (1982); Chicago Police Department, Murder Analysis 1980, at 16-18 (unpublished report on file witb The University of Chicago Law Review).

* A primary intersexual offender is the main instigator or weapon user, of opposite sex from the victim, in a homicide event. This characterization is made on the bases of the information contained in the pohice reports of the crime.

** Hispanic surname.

shows the same dramatic overrepresentation of blacks and underrepresentation of Hispanics in intersexual violence.

Black Chicago, representing approxinately $40 \%$ of the city's population, accounted for $71 \%$ of the city's known homicide offenders during 1980 and $78 \%$ of the known or suspected primary intersexual offenders during 1981. This overrepresentation-consistent with all contemporary studies of American urban homicide $^{18}$ - tends to suppress very important statistical patterns

16 Hispanics made up $\mathbf{1 3 . 5 \%}$ of those arrested for violent crimes (murder, forcible rape, robbery, and aggravated assault) in 1980, UNIFORM CRIMB REPORTs, supra note 2, at 207 (1980) (Table 36), although they represented only $6.4 \%$ of the national population, see BuREAU OF THE CEnsus, supra note 8, at 32 (1981) (Table 36).

${ }^{17}$ For further discussion, see infra part II-D.

16 See, e.g., J. Godwin, Murder U.S.A. 185 (1978); H. LundsgaArde, Murder in Space City 46, 50, 222 (Table VI) (1977); H. Rose \& P. McClain, Black Homicide and the URBan Environment 4-11 (Jan. 5, 1981) (Final Report to the Center for Minority Group Mental 
among the white and Hispanic populations. As Table 2 shows, white non-Hispanic Chicago residents, also approximately $40 \%$ of the population, are responsible for one in twelve total homicides but twice that proportion of intersexual killings. At the same time, offenders with Hispanic surnames drawn from (a probably underestimated) $14 \%$ of the population, are implicated in one of every five killings, but in less than one of every twenty intersexual homicides.

Table 3 shows the distribution of intersexual homicides in Chicago in 1981 by type of relationship shared by the victim and the offender.

The paradigmatic image of criminal homicide, that of a liusband killing his wife, accounts for only 1 out of every 100 Chicago homicides. Indeed, only 25 of the 151 intersexual killings occurred within a legal inarriage relationship known to the police, ${ }^{19}$ and spouse homicide made up only $2.6 \%$ of the total lomicides committed in Chicago in 1981. Based on 1980 census estimates, the spouse homicide rate in Chicago is 0.83 per 100,000 persons, ${ }^{20}$ or 4.9 per 100,000 married couples. ${ }^{21}$

The data in Table 3 also show the close association between intersexual killing and the existence of a prior personal relationship between victim and offender. In 1981 over half of all intersexual killings involved prior intimate or familial relationships; during 1980 , the comparable figure for intrasexual homicides was one in twenty-nine. ${ }^{22}$ At the otlier end of the scale, only $17.5 \%$ of intersexual killings involved killings by strangers or situations where a relationship could not be determined, while just over half of all

Health Problems and the National Institute of Mental Health, Grant \#5 RO1 MH 29269-02; reproduced by the U.S. Dep't of Health and Human Services, the Alcohol, Drug Abuse and Mental Health Administration, and the Nat'l Institute of Mental Health); UNIFORM CRIME RkPORTs, supra note 2, at 11, 216-18 (Table 42) (1980).

10 Police do not ask to see a marriage hicense or other proof of legal marriage. As we stated supra note 11, this information (or any information on household composition, length of relationship, etc.) is usually not pertinent to pohice investigations. As Table 3 reports, in 1981 there were two cases of divorced wives killing their former husbands, but we are unable to analyze the death risks associated with this relationship since Cbicago Pohice Department statistics lack this category.

${ }^{20}$ Bureau of the Census, supra note 8, at 22 (103d ed. 1982) (Table 26).

21 Census data report 465,620 households with married couples in the City of Chicago. Department of Planning, City or Chicago, 1980 Census Reports, Population (pt. 3) 13 (1982) (Table 15).

22 Compare Chicago Pohice Department, Murder Analysis 1980, at 15 (undated unpublished report on file with The University of Chicago Law Review) with Table 3, infra p. 917. 


\section{TABLE 3}

Percentage Distribution of Offender/Victim Relationships, Total Chicago Intersexual Homicide 1981

\section{1}

Intersexual Homicide Breakdown

(as percent of total homicide)

Intimate \& Familial

Husband/Wife Legal

Husband/Wife Common Law

Wife/Husband Legal

Wife/Husband Common Law

Ex-wife/Ex-husband

Boyfriend/Girlfriend

Girlfriend/Boyfriend

Other Relatives

\& Child Abuse

Male/Female

Female/Male

Friends \& Neighbors

Male/Female

Female/Male

Some Acquaintance

Male/Female

Female/Male

No Relation, Stranger

\& Unknown

Male/Female

Female/Male

Other Killings

(Intrasexual)

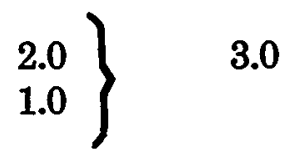

Total Homicide 
intrasexual homicides involved strangers or undetermined relationships. ${ }^{2 s}$

If legal marriage represents a haven from homicide, less formal intimate relationships appear more dangerous. As Table 3 reports, killings between police-classified "boyfriends" and "girlfriends" are slightly more frequent than are interspousal homicides, though characterizing these relationships as "boy/girl" is inaccurate, as is shown in Table 4.

\section{TABLE 4}

Percentage Distribution of Offender Ages, Total Chicago Homicide 1980 \& INTERSEXUAL Homicide 1981, By RelationshiP

\begin{tabular}{|c|c|c|c|c|c|}
\hline & $\begin{array}{c}\text { Legal } \\
\text { Marriage } \\
\end{array}$ & $\begin{array}{c}\text { Common Law } \\
\text { Marriage }\end{array}$ & $\begin{array}{c}\text { Romantic } \\
\text { Involvement }\end{array}$ & $\begin{array}{c}\text { Residual } 1981 \\
\text { Intersexual } \\
\text { Homicide } \\
\end{array}$ & $\begin{array}{c}1980 \\
\text { Homicide } \\
\text { Offenders } \\
\end{array}$ \\
\hline Under 21 & 0 & 6 & 8 & 33 & 27 \\
\hline 21-25 & 16 & 25 & 15 & 24 & 27 \\
\hline $26-30$ & 28 & 13 & 15 & 22 & 18 \\
\hline $31-35$ & 12 & 13 & 8 & 10 & 12 \\
\hline $36-40$ & 8 & 13 & 19 & 2 & 4 \\
\hline $41-45$ & 16 & 13 & 8 & 3 & 4 \\
\hline $46-50$ & 4 & 6 & 15 & 3 & 3 \\
\hline $51-55$ & 8 & 0 & 4 & 1 & 3 \\
\hline $56-60$ & 8 & 13 & 8 & 2 & 1 \\
\hline $61+$ & 0 & 0 & 0 & $\underline{0}$ & 1 \\
\hline Total ${ }^{*}$ & $\begin{array}{c}100 \% \\
(n=25)\end{array}$ & $\begin{array}{c}100 \% \\
(n=16)\end{array}$ & $\begin{array}{c}100 \% \\
(n=26)\end{array}$ & $\begin{array}{c}100 \% \\
(n=84)\end{array}$ & $\begin{array}{c}100 \% \\
(n=724)\end{array}$ \\
\hline
\end{tabular}

Sounce: Chicago Police Department, supra note 22, at 12; Homicide Records and Case Files of the Chicago Police Department.

* Percentages may not add up to $100 \%$ due to rounding.

The typical offender in all intimate homicides is older than the average homicide offender by about ten years (a median age of thirty-one to thirty-five as opposed to twenty-one to twenty-five), ${ }^{24}$ and age distributions across all three intimate categories are remarkably similar. If the "romantic involvement" homicide rates are higher than those for legal inarriage, this is perhaps a function

ss Compare Chicago Police Department, supra note 22, at 15 with Table 3, supra p. 917.

24 A similar age differential holds for intimate homicide victims: their median age at death is between 31 and 35 years, see supra Table 4, while that of the average homicide victim is between 26 and 30 years, Chicago Police Department, supra note 22, at 12. 
of the greater emotional or psychological instability of this population across all ages rather than of any higher propensity of young people to commit violent acts. ${ }^{25}$

Table 5 presents ratios of male to female involvement as intersexual offenders by race/ethnicity and type of relationship.

TABLE 5

\begin{abstract}
Ratio of Male to Female Involvement as Offenders, By Race/ EthnictTy aNd Relationship, Intersexual Homicide in Chicago, 1981
\end{abstract}

\title{
Male to Female Involvement by \\ Race/Ethnicity
}

Black White Hispanic Total

Spouse \& Romantic

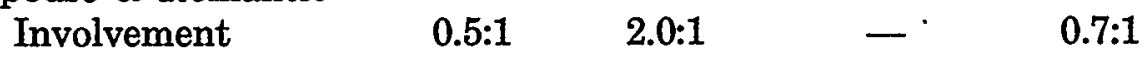

Family, Friends \&

Neighbors

$1.0: 1 \quad 4.0: 1$

1.2:1

Some Acquaintance,

No Relation \&

Unknown

2.8:1

1.5:1

$5.0: 1$

$2.6: 1$

Source: Homicide Records and Case Files of the Chicago Police Department.

The ratios differ considerably, depending both on the relationship between victim and offender and ethnic group. Non-Hispanic

${ }^{23}$ Estimating the number of boyfriend/girlfriend couples in the adult population would involve categorization on the basis of the answers to some rather arbitrary questions, for example, duration of relationship, shared as opposed to separate residence, amount of time spent together, or self-definitions of the relationship. We know of no attempts to estimate the size of this population, and our future research on lomicide in boyfriend/girlfriend relationships is dependent on further efforts in this area, as well as on collecting a larger sample of this type of intersexual homicide that spans at least a decade.

A further note of caution is required here. The distmction between "common law" relationships and those of boyfriend and girlfriend is a judgment call. Thus, the higher absolute level of intersexual killing associated with these more informal relational statuses cannot be estimated with any precision. "Common law" marriage, for example, is not legally recognized in Illinois, and its use by the Chicago Police Department is due either to (1) an ex nihilo creation, (2) a holdover from an eartier period, or (3) self-definitions by offenders and victims of both homicide and otler crimes. We were unable to obtain any real explanation of the difference between "common law" marriage and "boyfriend/girlfriend." One discriminant might be the presence or absence of children born to the couple; another might be selfdescriptions by offenders. For additional discussion of the problems inherent in categorization on the basis of relationship, see supra notes 11, 19,23 and accompanying text. 
white males kill females with whom they are intimate twice as frequently as they are killed, whereas black males are twice as likely to be killed by their female intimates as to kill them. Most surprisingly, no Hispanic-surnamed man or woman killed a spouse or romantic intimate in Chicago during 1981. Our initial reaction to this datum was disbelief, but reinspection confirmed tlie accuracy of the finding. ${ }^{26}$ The seven intersexual killings involving Hispanic offenders consisted of one "friend" case and six "some acquaintance" or "no relation" homicides. We consider these cases "spillovers" from the high incidence of male-male lomicide among Hispanics. ${ }^{27}$ In our view this pattern represents an exception to otlierwise violent male cultural values.

Table 6 examines weapon use by race, sex, and relationship in an attempt to explain the differential male to female kill ratios reported in Table 5. As one might expect, weapons other than the omnipresent American firearm and knife play a more important role in killings by males than by females. These otlier instrumentalities, principally physical force, account for about three out of ten intersexual killings by males, regardless of their race or the nature of their prior relationship with the victim. Black females used guns or knives in fifty-two of the fifty-seven intersexual homicides they committed.

The use of lethal force by females is again expectable, and the higher absolute number of firearm deaths among blacks may suggest greater firearm ownership among the population at risk in black louseholds than among tlose in white households. ${ }^{28}$ The

28 We found Hispanics similarly underrepresented in 1980 statistics for intersexual homicide in Chicago. In 1980 only 10 intersexual homicides involved Hispanic offenders and/or victims. Nine of the Hispanic offenders were male; the one female offender was a participant in a multi-offender homicide.

${ }^{27}$ See supra note 16 and accompanying text. The two killings by female Hispanic offenders are described infra at notes $44-45$ and accompanying text. All five male Hispanic offenders seemed to lack premeditated intent to kill a female victim. Their homicides consisted of two multiple-victim gang killings in which the intended victims were inale, one arson in which unintended victims were killed, a home invasion/burglary during which tbe victiun surprised the offenders, and one case in which two Hispanic male teenagers who fired at a drug dealer's windows inadvertently shot and killed a young black girl at her window in another building.

${ }^{26}$ Survey researcb data would tend to refute tbis suggestion, but those findings are suspect and somewhat dated. For example, the last two Gallup polls tbat measured gun ownership by race were taken in 1972 and 1975 . The 1972 poll reported that $45 \%$ of the whites interviewed owned guns, compared to $33 \%$ of the nonwhites. 1 G. Gallup, The GaLLUP PoLl $40-41$ (1978). The 1975 poll reported $50 \%$ gun ownership by white respondents and only $31 \%$ by nonwhites. Id. at 585-89. See also G. Newton \& F. Zimring, Firearms \& VIOLENCE IN AMERICAN LIRE 176-77 (1969) (gun ownership positively correlated with white income, negatively with black income). 


\section{TABLE 6}

OfFender's Weapon Use, for Blacks and Whites, By Relationship, Chicago Intersexual Homicide, 1981

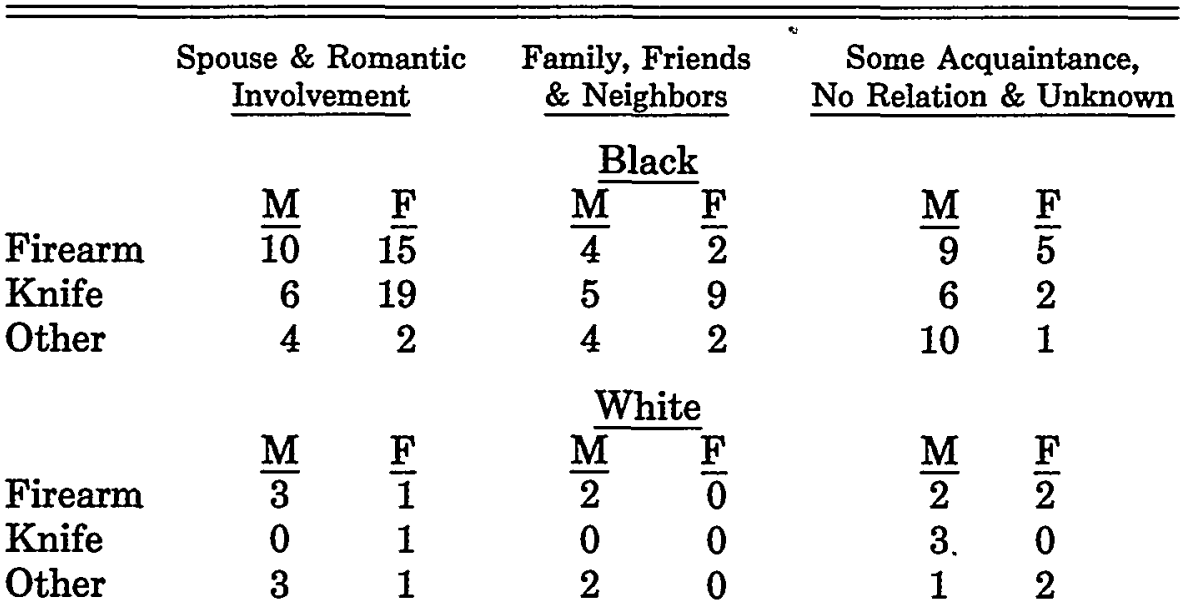

Source: Homicide Records and Case Files of the Chicago Pohice Department.

problem with inferring anything about gun ownership statistics from intersexual homicide rates is the thirty to one difference in knife use by black female offenders as compared to white female offenders; knives are available in both black and white households but have been used overwhelmingly by black women. Cultural rather than instrumentality effects dominate any analysis of the role of knives in intimate violence. Thus, instrumentality effects based on weapon availability can be only a partial explanation of the sharp reversal of male to female kill ratios between whites and blacks.

\section{Speculations and Hypotheses}

This is merely a preliminary analysis, but the temptation to speculate on the theoretical implications it raises is great. Our response to irresistible impulse can be organized under six headings.

\section{A. The Stability of Intimate Violence}

After increasing in the late sixties, rates of intimate lomicide stabilized and then declined; the general homicide rate underwent explosive expansion during the same period. ${ }^{29}$ Although this pat- 
tern produces no logically necessary conclusions, it is food for thought. Two preliminary hypotheses deserve mention. First, although the stabilization of intimate homicide rates occurred after great expansion in household handgun density, ${ }^{30}$ the low absolute numbers of intimate killings and the declining rates reported in Figure 1 suggest that gun availability is at most a necessary rather than a sufficient cause for the early increases in this class of homicides. Although a rise in the number of individuals carrying guns on the street produces dramatic increases in the death rates from assault and robbery, ${ }^{31}$ the impact of the increase in "house guns" on intimate violence appears more modest and may have been confined to the early years of America's domestic arms race..$^{32}$ Second, the sharply divergent trends in intimate and non-intimate homicide suggest that the two behaviors differ in kind rather than in degree.

\section{B. Racial Differences in Male-Female Kill Ratios}

Freud's observation that conduct is overdetermined ${ }^{33}$ is a good prehminary guide to the dramatic differences between male-female kill ratios that we observed when comparing intimate violence among whites to that among blacks. Several factors partially explain the gender differences in death rates. The greater physical strength of most males suggests that lethal weapons are a necessary condition for women killing men. The female offender-male victim homicide therefore requires the physical and psychological

so The number of handguns introduced into the civilian market quadrupled between 1962 and 1968, see G. NewTon \& F. Zimring, supra note 28, at 19 (Figure 4-2), and the number of spouse homicides imcreased $30 \%$ from 1318 to 1870 during this period, see Figure 1, supra p. 912. After 1968, handgun introduction stabilized at a high level of between 2.0 to 2.6 million new handguns per year, compared to 0.6 million in 1960 and 1.0 million in 1965 . See Bureau of THE Census, supra note 8, at 803 (102d ed. 1981) (Table 1453). Because there is no generally accepted method of measuring handgun removals, we have no firm basis for estimating the total number of handguns currently owned by American civilians.

s1 See, e.g., Zimring, Determinants of the Death Rate From Robbery: A Detroit Time Study, 6 J. Legar Stud. 317, 321, 326-27 (1977); Zimring, The Medium is the Message: Firearm Caliber as a Determinant of Death from Assault, 1 J. Legal Stud. 97, 109-13 (1972).

s2 Lest there be some readers who take this as evidence that firearms availability is irrelevant to spouse homicide, we refer them to Wolfgang's classic study, M. Wolfanan, Patterns in Criminal Homidide (1958). Wolfgang studied all homicides committed in Philadelphia from 1948 through 1952 (shortly after the historically unprecedented and massive introduction of firearms into American households following World War II). Firearms were used in $34 \%$ of the spouse homicides in his sample, id. at 213 (Table 26), a level nearly equal to the $40 \%$ firearm use we found, see Table 6, supra p. 921.

ss See, e.g., S. Freud, The InTERPRETation of Dreams 403 (1921). 
availability of either knives or guns. This notion of psychological availability is not just whimsy: we have never encountered a household without a knife, but the two to one kill ratio between white males and white females strongly suggests that cultural or psychological patterns block white women from escalating domestic violence through recourse to knives. Indeed, the substantial difference observed between black females' and white females' recourse to knives suggests cultural patterns are a highly significant determinant of (and for whites, a restraint on) female use of lethal counterforce. Thus while the average greater physical prowess of men makes it more likely that any given intimate homicide victim will be a woman, the psychological and cultural restraints on women described above probably operate to reduce the total number of intimate killings.

The almost two to one kill ratio favoring black women (in the spouse and romantic involvement categories) and the relatively low number of intersexual homicides committed by black males also suggest what we tentatively will call a "male restraint" hypothesis. Although black male rates of homicide are generally ten or more times those noted for white males, ${ }^{34}$ the black male rates of intersexual killing we observed are only 3.4 times white rates. ${ }^{35}$ This suggests a "chivalry" limitation on what has been characterized as a culture of violence. It may be considered unmanly to use letlial force on women, even thougl physical beatings are more frequent, ${ }^{36}$ and many black women probably are much closer to the instruments and values of violence as a problem solving meclianism. This may lead to more pronounced inclinations among black females to escalate violent confrontations to the point of using lethal force, while black males, even if they were the initial aggressors, are deterred from the initial resort to lethal force because it may be considered unmanly or unnecessary. The statistics suggest that higher female weapon use results in a ligher proportion of male victims and a ligher rate of homicide.

st See, e.g., Block \& Zimring, supra note 2, at 4; Chicago Police Department, supra note 22 , at 16 .

ss In 1981 the rate of intersexual killings committed by black males in Chicago was 10.6 per 100,000 black males, versus 3.1 for white males. Compare Table 2 and Table 6, supra pp. 915 \& 921, with BUREAU of THE Census, supra Table 2, at 372.

s6 M. Strauss, R. Gelles \& S. Steinmetz, supra note 3, report that black husbands beat their wives nearly four times as frequently as white males do, and that black wives engage in violence toward their husbands twice as frequently as white females do, $i d$. at 128 29 (Chart 10). Thus the need for counterforce by black females is obviously much greater. 


\section{Legal Marriage as Life Insurance}

Homicide within formal family settings is extraordinarily rare. Whether the standard of comparison is the general homicide rate, race-specific homicide rates, or even intersexual homicides within less structured intimate relationships, "spouse killing" is an infrequent phenomenon. ${ }^{37}$ Spouse homicide rates in the United States are much more comparable to the low homicide rates in other Western nations than are our rates for broader categories of violent crime. ${ }^{38}$

This counter-criminogenic significance of legal marriage is not easy to interpret. One plausible partial explanation is that those still legally married to each other are a self-selected population with respect to stability, particularly since divorce is an accessible alternative to the chronic violent interactions that can escalate into killing.

Legal marriage and the low rates of spouse homicide noted in this study are intriguing terrain for those who wish to study the origins and control of violent impulse. The actual number of marital conflicts is uncountable. Recent survey research, however, estimates (doubtlessly underestimates) that there were 16,673 violent acts per 100,000 married couples in $19800^{39}$ Projected onto national spouse homicide statistics, this results in a ratio of violent events to homicides within legal marriage of at least 4715 to 1 for that year..$^{40}$ If this estimate has any range of accuracy as a minimum

${ }^{37}$ For example, we found that of the 877 homicides committed in Chicago in 1981, only 25 were spouse killings. See Table 4, supra p. 918.

38 In 1980, for example, there were 1.8 spouse homicides for every 100,000 married persons. See BurEau of THE CENsus, supra note 8, at 38 (103d ed. 1982) (Table 47); supra note 10. By comparison, the general homicide rate in the United States was 10.2 per 100,000 inhabitants. UNIFORM CRIME REPORTS, supra note 2, at 7 (1980). The rate of black homicide was 34.8 victims per 100,000 black residents; the rate for whites was 6.0 per 100,000 . Compare UnIrorm CRIme Reports, supra note 2, at 11 (1980) (number of victims) with BuREAU or THE CENSUS, supra note 8, at 26 (103d ed. 1982) (Table 28) (population statistics). In 1978, when the homicide rate in the United States was 9.4 per 100,000 inhabitants, the rates in Western European Countries varied from 5.7 in Northern Ireland to 0.5 in Denmark. See id. at 179 (Table 297).

so Based upon survey responses, the researchers posited that partners in one in six married couples commit at least one violent act against their spouses each year. See M. STrauss, R. Geiles \& S. Steinmetz, supra note 3 , at 32.

10 If there were 16,673 violent acts per 100,000 married couples in 1980 , then based on a population of 102.6 million married people in the United States in 1980, BUREAU OF THE CENSUS, supra note 8 , at 38 (103d ed. 1982) (Table 47), there were at least 8.553 million violent acts between marriage partners that year. Since only 1814 of these resulted in homicide, see supra note 10, the ratio of violent acts to homicides is at least 4715:1. We suspect that the actual number and rate of violent events is much greater (by anywhere from 50$200 \%$ ) and thus that the ratio of violent events to spousal homicide is correspondingly 
figure, the ratio of conflict to killing in man-woman relationships and particularly in legal marriage is probably higher than in almost any other arena of adult American life. Unlike organized sports, however, there is no referee in the private sphere of marital violence.

In light of the prevalence of spousal conflict, perhaps we should examine not why there are so many intimate homicides, but rather why there are so few within the turbulence of marital intimacy. Low rates of females killing females and of female homicide generally ${ }^{11}$ might suggest that there are perceptions about the nature of the woman's role that limit resort to lethal force agamst women by both male and female actors. If so, what is the dynamic, and how will it change as women's roles and perceptions of those roles are redefined? We are far from answers to these questions but consider them to be ones well worth asking.

\section{The Origins and Future of the Hispanic Family "Taboo"}

The discontimuity between intersexual and intrasexual homicide is nowhere more evident than among Chicago's Hispanic population, a group composed of substantial numbers of persons with Mexican and Puerto Rican origins. This population generates $20 \%$ of all Chicago homicide suspects, ${ }^{42}$ but produced only $3 \%$ of the intersexual killings in Chicago in 1981. Further, there were no cases where conflict escalated to killing that involved a victim and offender with Hispanic surnames who had a romantic or familial relationship.

The metaphor we would use to describe the total absence of intimate homicide in this ethnic group is that of taboo. The data suggest more than an exception for women in a cultural system otherwise supportive of violent solutions to conflict. Instead, we suspect feehings of abhorrence among Hispanic men toward using lethal force against women.

The pattern among Hispanic women may be different. Putting aside episodic reports of adolescent female gang behavior, we possess no substantial evidence that cultural values favor violent solutions to disputes among Hispanic women. Thus there may be little violence to spill over into domestic or familial situations. Further-

understated.

11 Females made up only $12.8 \%$ of those arrested for homicide in 1980 , and only $10.0 \%$ of those arrested for violent crimes generally that year. See UNIFORM CrIME REPORTs, supra note 2, at 203 (1980) (Table 34).

42 See Chicago Pohce Department, supra note 22, at 12, 17. 
more, unlike black women, ${ }^{43}$ Hispanic women in Chicago might not experience the same need for counterforce generated by male aggression.

The only two cases in our sample involving female offenders with Hispanic surnames in colorably intimate situations invite further speculation on the future of this pattern. The first case involved a woman killing a black male "roommate."44 Are the taboos we speak of endogenous, to continue the metaphor, or is the need for counterforce perceived as greater when Hispanic women are dealing with non-Hispanic men? The second case involved a prostitute who was charged with accessorial hability for the armed robbery and murder of a customer by her pimp/lover. ${ }^{45}$ Here the exception may prove the rule: the actual use of lethal force was by a male against a male.

All this leads to one final speculation: what happens to the taboo among second- and third-generation successors to this recently arrived Latin immigrant cohort? One issue is whether the values that block intimate aggression by males against females will be successfully transmitted to younger group members. A second issue concerns the impact of cultural desegregation of intimate relationships. Intercultural intimacy may change both the values associated with violent problem solving and the situational pressure on women when dealing with non-Hispanic males. Further research on these matters, particularly in cities like Los Angeles and New York, which have large second-generation populations of Hispanic-surnamed adults, may have a lot to teach us. ${ }^{46}$ The passage

4s See supra note 36 and accompanying text.

14 The offender had her own room in the victim's apartment. Arguments had occurred frequently, and during one the offender stabbed the victim and then called the police; when they arrived, the victim had died. The investigative file contained no hints of sexual intimacy between the victim and the offender.

45 The victim, a young Hispanic male, was flashing a roll of about $\$ 200$ in a bar when he was solicited by the female offender. They went into an adjacent alley and the victim was set upon by the prostitute's gun wielding companion. The victim resisted and was shot to death.

46 We suspect that the incidence and rates of intersexual homicide among second- and third-generation populations of New York Puerto Ricans and Los Angeles Chicanos is much higher than for Chicago. We do have one piece of inconclusive evidence from a study our senior author is conducting on youth violence in New York City covering the period January 1974 through June 1981. See F. Zimring, Youth Homicide in New York: A Preliminary Analysis 12-13 (Oct. 26, 1982) (unpublished manuscript on file with The University of Chicago Law Review). Intersexual homicides by Hispanic offenders comprise $4.9 \%$ of the total homicides' $(n=1244)$ in the youth homicide sample of this study (which includes all cases where the youngest arrestee was aged 19 years or under). The New York adult sample $(n=472)$ includes a slightly greater percentage of Hispanic intersexual killings $(6.8 \%$ of total homicides) but we place less reliance on it. (The adult sample consists of the first five 
of time will also prove instructive.

E. The Connection Between Intimate and Other Lethal Violence

Cultural values are vital and complicated determinants of patterns of violent behavior. The critical nature of social values is acknowledged in the literature, but not the complexities across and within subcultures that produce so many of the striking differences in this study. A general "culture of violence" and the availability of lethal force are necessary but not sufficient conditions for high rates of violence between the sexes. Attitudes toward both gender and family are supremely important determinants of homicide rates in intimate relationships.

\section{F. Violence Research and Substantive Criminal Law}

There are many reasons why a rational criminal law of violence depends heavily on behavioral research. Only one such linkage will be mentioned here: the relationship between knowledge of the reality of homicide and a rational criminal sentencing policy.

The criminal law of homicide evolved into a lengthy hodgepodge of distinctions, many going to moral turpitude or length of sentence, that have been elegantly analyzed by Wechsler and Michael. ${ }^{47}$ The response of law reformers, including Professor Wechsler, has been to reduce the criminal law of homicide, particularly the definition of murder, into the ultimate Reader's Digest condensed book. Illinois, for instance, following in the tradition of the Model Penal Code, provides:

A person who kills an individual without lawful justification commits murder if, in performing the acts which cause the death:

(1) He either intends to kill or do great bodily harm to that individual or another, or knows that such acts will cause death to that individual or another; or (2) $\mathrm{He}$ knows that such acts create a strong probability of death or great bodily harm to that individual or another; or (3)

homicide cases in each month in which the youngest arrested offender was aged 20 years or older.) By comparison, Hispanic intersexual killings are a paltry $0.6 \%$ of the total homicides committed in Chicago in 1981, see Tahle 1, supra p. 914; supra note 12 and accompanying text, and they comprise only $1.5 \%$ of total hoinicides committed between 1977 and 1981, see Homicide Records and Case Files of the Chicago Police Department.

47 Wechsler \& Michael, A Rationale of the Law of Homicide (pts. 1 \& 2), 37 Colum. L. REv. 701, 1261 (1937). 
He is attempting or committing a forcible felony other than voluntary manslaughter. ${ }^{48}$

This simplification was possible because the Model Penal Code's schedule of punishments provides judges and parole release authorities with substantial sentencing discretion. ${ }^{49}$ Even where justice requires different measures of punishment, dissimilar acts can be lumped together under a single substantive definition, since it does not determine the nature or the duration of punishment.

Another example of the tendency to condense homicide laws is the former statute defining second degree murder in Pennsylvania. Hardly a model of clarity or specificity, the statute provided:

\section{\$2501. Criminal Homicide}

(a) Offense defined.-A person is guilty of criminal homicide if he intentionally, knowingly, recklessly or negligently causes the death of another human being.

(b) Classification.-Criminal homicide shall be classified as murder, voluntary manslaughter, or involuntary manslaughter. \$2502. Murder

(a) Murder of the first degree.-A criminal homicide constitutes murder of the first degree when it is committed by means of poison, or by lying in wait, or by any other kind of willful, deliberate, and premeditated killing. A criminal homicide constitutes murder of the first degree if the actor is engaged in or is an accomplice in the commission of, or an attempt to commit, or flight after committing, or attempting to commit robbery, rape, or deviate sexual intercourse by force or threat of force, arson, burglary, or kidnapping.

(b) Murder of the second degree.-All other kinds of murder shall be murder of the second degree. Murder of the second degree is a felony of the first degree..$^{\text {so }}$

The saving grace of this omnibus definition of second degree murder was that upon conviction, a judge could impose a sentence that varied between probation and twenty years in the penitentiary. Of special relevance to our present study of intimate violence

4s Criminal Code of 1961, § 9-1(a), Ill. Rev. Stat. ch. 38, § 9-1(a) (1982); see also id. $\S$ 9-2(a)-(b) (manslaughter offenses that are frequently employed in spouse homicide cases as reduced charges).

40 See Model Penal Code $\$ \$ 6.01,6.06$ (Proposed Official Draft 1962).

so 18 PA. Cons. Stat. ANN. $\$ \S 2501-2502$ (Purdon 1973) (emphasis added) (current version at 18 PA. Cons. Stat. AnN. $\$ 2502$ (Purdon Supp. 1981)). 
is that in an earlier study by the senior author regarding homicide sentencing patterns in Philadelphia, fully half of the females in the sample who were convicted of some criminal homicide offense were not sentenced to prison. ${ }^{51}$ Thus as long as the definition of offenses was effectively separated from the determination of individual punishments, moral turpitude and legal punishment could be decided one case at a time.

Discretion has its drawbacks, however, and the contemporary criminal law reform movement strives to link the definition of offenses to particular punishments less flexibly than in either previous twentieth-century criminal law or the system the Model Penal Code envisioned. ${ }^{22}$ Under these "new wave" reforms, a legislator or sentencing commission must decide on a just punishment in advance of the commission of any crimes. To do so without detailed behavioral knowledge of patterns, motives, correlates, and characteristics of offenders in particular subclasses of homicide seems arbitrary in the extreme. Any responsible attempt to make the punishment fit the crime must pay far more attention to the behavioral reality of criminal violence than has current legislation or any existent law reform effort of which we are aware.

Having explored the vignettes of human misery and culpability that lie behind the tables and charts in this study, we are moved to beheve that there can be no "fixed price" sentencing in the criminal law of intimate violence. We observed variations in the degree of emotional instability, in provocation, in intent to cause grievous harm or death, and in sheer cruelty that are simply too great to be domesticated into two or three grades of crime with relatively narrow punishment ranges. This is not to assert that any system built around determinate sentencing ranges will not function. The multiple layers of discretion already built into the criminal justice system will produce results roughly consistent with the prosecutor's sense of justice, but unfortunately this can happen only at the expense of the conscious nulliflcation of the substantive criminal law. ${ }^{58}$ Must we ignore the principles of penal law to

s1 Unpublished data gathered for the study reported in Zimring, Eigen \& O'Malley, Punishing Homicide in Philadelphia: Perspectives on the Death Penalty, 43 U. CHI. L. REv. 227 (1976).

ss See, e.g., ModrL Penal. Code, supra note 49, §§ 6.01-6.130.

ss Voluntary manslaughter is the saving grace of omnibus murder statutes. See, e.g., Criminal Code of 1961, § 9-2, InL. Rev. Stat. ch. 38, § 9-2 (1982); Moder. Penal Code, supra note $49, \S 210.3$. This is an offense that allows probation in many jurisdictions.

The point we make about nullification of the substantive criminal law, however, can best be illustrated by two hypotheticals. Assume in the first case that there is a long history 
achieve equity? Or are there other ways to deal with the problems of sentence disparity and uncontrolled discretion?

\section{ConcLusion}

This paper is rife with speculation for a study involving only 151 cases in one midwestern American city. Tentative hypotheses have special value, however, when so much has been left unexamined. We need a new interdisciplinary tradition in the study of violence. Anthropology, law, social psychology, and statistical criminology have missed critical opportunities for collaboration. As a result, a set of important questions remains unasked and unanswered.

of a husband who severely beats his wife. During one such beating the wife defends herself and kills her husband. Under Illinois law she has committed voluntary manslaughter, see Criminal Code of 1961, §§ 7-1, 9-2, ILL. REv. STAT. ch. 38, §§ 7-1, 9-2(b) (1982), but who is going to prosecute her? None of us would. Assume that in the second case there is a situation of extreme and protracted marital conflict, one that has never previously escalated to violence. During one such argument the wife finally pulls a gun and shoots her husband dead. She has committed murder under Illinois law, see id. § 9-2, ILL. REv. Stat. ch. 38, § 9 1(a) (1982), but who would give her life imprisonment? Not us, and we suspect not prosecutors. 